IRSTI 06.35.31

UDC 657.631

https://doi.org/10.46914/1562-2959-2021-1-1-31-38

\author{
A.S. BIKTEUBAYEVA, ${ }^{\text {* }}$ \\ $\mathrm{PhD}$ associate professor. \\ *e-mail: a.bikteubayeva@turan-edu.kz \\ K.ZH. ELSHIBEKOVA, ${ }^{1}$ \\ master, senior lecturer. \\ e-mail:k.elshibekova@turan-edu.kz \\ ${ }^{1}$ Turan University, Kazakhstan, Almaty
}

\title{
THE USE OF ANALYTICAL PROCEDURES AT THE AUDIT PLANNING STAGE
}

\begin{abstract}
The article considers the main stages of an audit. They allow to achieve the main goal of audit planning, that is, the implementation of a reporting test to identify possible errors; reporting testing for probable errors; horizontal and vertical analysis and "reading" of reports; express analysis of reporting. At the stage of planning the audit, after the disclosure of inconsistencies in the forms of financial statements, significant changes in the dynamics and structure, it is possible to determine the coefficients and at the same time the method of express analysis of the statements is used. The article focuses on the main mistakes in financial reporting. The main ratios for the analysis of financial statements are also given: liquidity ratios; financial stability; turnover; profitability. The analytical procedures presented in the article, which are guided by auditors at the stage of planning an audit, can be divided into the following groups. In addition, the division of audit procedures helps to identify problems in the provided information in a timely manner when disclosing it in the financial statements, and is aimed at identifying audit risks at the substantive stage. The use of analytical procedures at the stage of planning an audit allows you to create an audit program with minimal time costs, reduce the risks of problems that are associated with a lack of time and skills of personnel.
\end{abstract}

Key words: audit, reporting, analytical procedures, audit review, planning, auditors, finance.

An important stage of the audit, which decides what will be the strategy and detailed approaches to the scope of audit procedures, the timing of the implementation, the expectation of the result - is the planning of the audit. The planning process takes into account the specifics of each entity subject to audit.

One of the main objectives of the audit planning stage is to identify possible risks, information in which there are errors and, on this basis, to assess the scope of procedures performed at the next stages of the audit.

The use of analytical procedures in audit planning was discussed in more detail in the works of d.o.e. N. A. Kazakova [1], c.o.e. E. S. Surnina [2], Sh. I. Alibekov [3], A.V. Tereshkina [4] and others.

There are several types of analytical procedures that allow you to achieve the main goal of audit planning, namely:

- conducting a reporting test to identify possible errors;

- testing the reporting for possible errors;

- horizontal and vertical analysis and «reading» of reports;

- express analysis of reports.

It is worth noting that the division of analytical procedures into several types is conditional, in practice, most often there is a parallel execution of these procedures, without a clearly defined sequence. Let's analyze each of the types separately.

Conducting a test of financial statements to identify possible errors is one of the first analytical procedures that should be performed by the auditor at the stage of planning the audit.

The most common errors in the financial statements are shown in figure 1 (p. 32).

Organizational and technical errors can be identified by the auditor at the stage of audit planning, methodological errors - when performing substantive procedures.

To identify organizational errors, the auditor should check the number of financial reporting forms, as well as the correctness of filling in the required details in them. 
Organizational (formal) - related to incorrect determination of the composition of accounting (financial) statements, the frequency of its preparation, filling in certain details, violation of the rules for signing, etc.

Technical - mainly represented by arithmetic errors, inconsistencies between indicators of different reporting forms, or lines in the same form due to incorrect calculations, negligence, or other reasons.

Methodology errors - those that have appeared in connection with incorrect accounting, violation of the standards provided for by law, and the rules of accounting policy.

Figure 1 - Errors encountered in the financial statements

Note - Developed by the authors.

In order to ensure that there are no technical errors in the financial statements, the auditor should perform an analytical procedure related to checking the correlation of the indicators of the reporting forms.

To confirm the arithmetic correctness of the data in one form of financial statements, the auditor must sum up the indicators of each of the sections or lines and compare the resulting result with the final value [5].

When testing reports for the presence of «technical errors» in it, it is important to check the arithmetic correlation of indicators of different reporting forms with each other. Let us illustrate the considered analytical procedure with examples (Table 1).

Table 1 - Equality between items f. 1-B «Balance sheet» and f. 2-OPU «Income statement» f. 5-I «Statement of changes in equity»

\begin{tabular}{|c|c|c|c|}
\hline $\begin{array}{c}\text { Balance } \\
\text { sheet }\end{array}$ & Compliance & $\begin{array}{l}\text { Other } \\
\text { forms }\end{array}$ & Indicators \\
\hline \multirow[t]{2}{*}{1} & 2 & 3 & 4 \\
\hline & \multicolumn{3}{|r|}{ STATEMENT OF PROFIT AND LOSS } \\
\hline $\begin{array}{l}\text { String } \\
414\end{array}$ & $=$ & $\begin{array}{l}\text { String } \\
300\end{array}$ & $\begin{array}{l}\text { Total profit (total loss) for the period. } \\
\text { Discrepancies are possible in two cases: } \\
\text { - when spending retained earnings in the reporting period on the basis of } \\
\text { decisions of the owners of the JSC (LLP). For example, for the payment } \\
\text { of dividends, repayment of losses of previous years, increase in the } \\
\text { authorized capital and other purposes; } \\
\text { - with mandatory contributions to the reserve capital (for JSC). } \\
\text { STATEMENT OF CHANGES IN EQUITY }\end{array}$ \\
\hline $\begin{array}{l}\text { String } \\
410\end{array}$ & $=$ & $\begin{array}{l}\text { String } \\
400\end{array}$ & Authorized capital at the beginning of the reporting period \\
\hline $\begin{array}{l}\text { String } \\
414\end{array}$ & $=$ & \begin{tabular}{|l} 
String \\
400
\end{tabular} & $\begin{array}{l}\text { Retained earnings (uncovered loss) at the beginning of the reporting } \\
\text { period }\end{array}$ \\
\hline $\begin{array}{l}\text { String } \\
420\end{array}$ & $=$ & $\begin{array}{l}\text { String } \\
400\end{array}$ & Total equity and reserves at the beginning of the reporting period \\
\hline $\begin{array}{l}\text { String } \\
410\end{array}$ & $=$ & \begin{tabular}{|l} 
String \\
800 \\
\end{tabular} & Authorized capital at the end of the reporting period \\
\hline $\begin{array}{l}\text { String } \\
414\end{array}$ & $=$ & \begin{tabular}{|l} 
String \\
800
\end{tabular} & Retained earnings (uncovered loss) at the end of the reporting period \\
\hline $\begin{array}{l}\text { String } \\
420\end{array}$ & $=$ & $\begin{array}{l}\text { String } \\
800\end{array}$ & Total equity and reserves at the end of the reporting period \\
\hline
\end{tabular}


The auditor should make sure that the indicator for line 500 «Total capital» of section 5 of the «Balance Sheet» at the beginning of the reporting year does not differ from the data for line «Balance as of January 1 of the reporting year» of the «Statement of Changes in Equity» at the end of the previous year. And only in cases of changes in legislation, or changes in accounting policies or corrections of errors of previous years, the indicators can show a difference. If there were such changes, then naturally, they should be reflected in the financial statements, and the user of the statements understood the reasons for the inconsistencies at the beginning and end of the periods.

The change for the period under line 414 «Retained earnings» on the balance sheet should be reflected and correspond to the indicators in the form "Statement of Changes in Equity». But at the same time, possible expenses of the net profit of previous years for various purposes are taken into account.

Thus, the analytical procedure, which is a test of financial reporting forms for the presence of arithmetic errors, helps the auditor at the audit planning stage to identify potential risks of incorrect reporting of indicators that need to be paid special attention to when conducting substantive procedures.

«Reading the financial statements» at the audit planning stage allows the auditor to get acquainted with the company on the basis of these reporting forms, identify trends in the main performance indicators, qualitative changes in its property and financial position, as well as identify priority areas of reporting for further analysis and verification during substantive procedures [6].

Table 2 below shows an example of the outcome options that the auditor can come to when «reading» the balance sheet.

Table 2 - Auditor's conclusions in the «reading the balance sheet» procedure

\begin{tabular}{|c|c|c|}
\hline \multirow[t]{2}{*}{ Section / Article } & \multicolumn{2}{|c|}{ Conclusion } \\
\hline & Increase in the indicator & Decrease in the indicator \\
\hline 1 & 2 & 3 \\
\hline $\begin{array}{l}\text { Section } 1 \ll \text { Short-term } \\
\text { assets». } \\
\text { 1. Cash. }\end{array}$ & \multicolumn{2}{|c|}{$\begin{array}{l}\text { Both the increase and decrease in the numerical indicator for this article does not } \\
\text { allow the auditor to draw any significant conclusions }\end{array}$} \\
\hline $\begin{array}{l}\text { Page } 015 \text { «Short-term } \\
\text { accounts receivable» (it } \\
\text { is advisable to consider } \\
\text { in conjunction with the } \\
\text { indicator of income } \\
\text { from sales) }\end{array}$ & $\begin{array}{l}\text { If the increase is due to higher sales } \\
\text { volume, the conclusion is that the } \\
\text { growth of income AO (LLP) was due to } \\
\text { changes in the credit policy, extend trade } \\
\text { credit, delayed payments. } \\
\text { If the increase occurs, but at the } \\
\text { same time the revenue decreases, the } \\
\text { conclusion is as follows: JSC (LLP) } \\
\text { fails to raise customer loyalty, despite } \\
\text { the improvement of the credit policy } \\
\text { towards customers. And this is a sign of } \\
\text { an increase in the operational risks of the } \\
\text { JSC (LLP). }\end{array}$ & $\begin{array}{l}\text { If the decrease occurs together with } \\
\text { an increase in sales revenue, then the } \\
\text { conclusion is that buyers pay their bills } \\
\text { earlier (either there was a reduction } \\
\text { in the terms of deferred payments, or } \\
\text { payment on prepayment). } \\
\text { If the income decreased, then the debt } \\
\text { of customers decreased. }\end{array}$ \\
\hline Page 018 «Inventory» & $\begin{array}{l}\text { A large number of stocks and } \\
\text { their annual growth may indicate } \\
\text { overstocking, as well as the recognition } \\
\text { in the accounting and reporting of stocks } \\
\text { with signs of impairment }\end{array}$ & $\begin{array}{l}\text { A regular decrease in inventory } \\
\text { shows both a decrease in business } \\
\text { activity, that is, a reduction in the } \\
\text { scale of activity, and a lack of funds } \\
\text { to purchase the necessary amount of } \\
\text { inventory. }\end{array}$ \\
\hline $\begin{array}{l}\text { Section } 2 \ll \text { Non-current } \\
\text { assets» }\end{array}$ & $\begin{array}{l}\text { The increase indicates the acquisition } \\
\text { of property or investment. If there is a } \\
\text { significant increase in one of the articles } \\
\text { in this section, then it is necessary } \\
\text { to analyze the articles of obligations } \\
\text { to determine at what expense these } \\
\text { investments were made. }\end{array}$ & $\begin{array}{l}\text { The decline shows both the sale of } \\
\text { fixed assets and depreciation, which } \\
\text { indicates the physical obsolescence of } \\
\text { fixed assets. }\end{array}$ \\
\hline
\end{tabular}


Continuation of table 2

\begin{tabular}{|c|c|c|}
\hline $\begin{array}{l}\text { Page } 213 \text { «Short-term } \\
\text { accounts payable» } \\
\text { (needs to be analyzed by } \\
\text { type of debt) }\end{array}$ & $\begin{array}{l}\text { The increase in debt to suppliers also } \\
\text { evidence of delayed payments, that is, } \\
\text { the violation of JSC (LLP) financial } \\
\text { discipline and agreements to increase the } \\
\text { time delay resulting in the conservation } \\
\text { of the volume of purchases, there is a } \\
\text { good relationship. An increase in tax } \\
\text { liabilities indicates an increase in the tax } \\
\text { risk of the organization }\end{array}$ & $\begin{array}{l}\text { The reduction in debt indicates } \\
\text { both a more stringent credit policy } \\
\text { of suppliers, and the availability of } \\
\text { advance payments for products. } \\
\text { The decrease in tax liabilities shows } \\
\text { both their timely fulfillment and the } \\
\text { decrease in the amount of taxes due to } \\
\text { a decrease in the business activity of } \\
\text { the JSC (LLP). }\end{array}$ \\
\hline Page 210 «Loans» & \multicolumn{2}{|c|}{$\begin{array}{l}\text { The auditor may indicate the presence of short-term or long-term loans from JSC } \\
\text { (LLP), an increase or decrease in their amounts. But it will not be possible for the } \\
\text { auditor to make a conclusion about the effectiveness of the use of credit funds, } \\
\text { since there is not enough information for this. }\end{array}$} \\
\hline $\begin{array}{l}\text { Page } 410 \ll \text { Authorized } \\
\text { capital» }\end{array}$ & \multicolumn{2}{|c|}{$\begin{array}{l}\text { Changing the articles of the Charter capital, as a rule, occurs only in the case of re } \\
\text { JSC (LLP) (for example, change of ownership, the issue of additional shares, etc.). }\end{array}$} \\
\hline $\begin{array}{l}\text { Page } 414 \text { «Retained } \\
\text { earnings (uncovered } \\
\text { loss)» }\end{array}$ & \multicolumn{2}{|c|}{$\begin{array}{l}\text { At the stage of « reading» the statements, the auditor needs to pay attention to } \\
\text { the «loss» indicator - the article shows the problems in the JSC (LLP), and when } \\
\text { conducting substantive procedures, and when assessing the continuity of the } \\
\text { company's activities. But to identify the reasons for the decline in this indicator and } \\
\text { for a detailed analysis, there is not enough data in the balance sheet. }\end{array}$} \\
\hline
\end{tabular}

As a rule, simultaneously with the «reading» of the financial statements, the auditor applies analytical procedures related to the elements of financial analysis - horizontal and vertical analysis of the financial statements.

Horizontal analysis is a comparison of the indicators of the reporting period with the indicators of previous periods. In this case, deviations are determined: absolute - this is in the monetary meter and relative - this is in percentages, fractions.

When applying horizontal analysis, you should consider the following:

a) it should be carried out if there are several analyzed periods, because in this case it is possible to track the dynamics of changes in funds and their sources;

b) such an analysis is impractical in a period of inflation, since in this case an increase in some indicator is associated with an increase in prices, but not with the scale of production.

At the planning stage, horizontal analysis helps to identify significant changes in some indicators, as well as the associated potential risks associated with incorrect accounting of transactions, as well as the risks of incompatibility of indicators reflected in different time periods.

The vertical analysis determines the structure of the indicators, while identifying the impact of each reporting item on the overall result. The purpose of such an analysis is to be able to analyze the whole by means of individual elements, to determine its structure and all changes in it. (Table 3 ).

Table 3 - Vertical analysis, using the example of the article «Stocks»

\begin{tabular}{|l|c|c|c|c|c|}
\hline \multicolumn{1}{|c|}{ Articles } & $\begin{array}{c}\text { Indicator } \\
\text { at the beginning } \\
\text { of the period, } \\
\text { thousand tenge }\end{array}$ & $\%$ of total & $\begin{array}{c}\text { Indicator at the } \\
\text { end of the period, } \\
\text { thousand tenge }\end{array}$ & $\%$ of total & $\begin{array}{c}\text { Absolute } \\
\text { deviation, } \\
\text { thousand tenge }\end{array}$ \\
\hline Stocks, including & 495 & $100 \%$ & 510 & $100 \%$ & 15 \\
\hline Raw materials and supplies & 180 & $36 \%$ & 18 & $4 \%$ & $(162)$ \\
\hline Work in progress & 265 & $54 \%$ & 25 & $5 \%$ & $(240)$ \\
\hline Finished products & 10 & $2 \%$ & 428 & $84 \%$ & 418 \\
\hline Deferred expenses & 40 & $8 \%$ & 39 & $7 \%$ & $(1)$ \\
\hline Note - Compiled by the authors from the audit materials. & & & \\
\hline
\end{tabular}


The example shows that with small changes in the final indicator for the item "Reserves" at the end of the period compared to the beginning, there were significant changes in its structure. At the beginning of the period, work in progress accounted for $54 \%$ and raw materials and supplies for $36 \%$, and at the end of the period - finished products for $84 \%$.

Horizontal and vertical analysis complement each other. And auditors develop comprehensive analytical tables that show both the structure and dynamics of indicators. The results of these types of analysis are valuable, because they help to analyze the reports of different types and volumes of production of the company.

At the planning stage of the audit, after the discrepancies between the amounts of the financial statements and significant changes in the dynamics and structure have been identified, it is possible to calculate the coefficients using the express analysis of the statements.

The purpose of the express analysis of the financial statements is to determine the financial position and condition of the company. Namely, the dynamics of income and expenses, the structure of assets and liabilities. This type of analysis is more suitable for the audit planning stage, since it is intended to determine the scope of the audit, its strategy and timing [7].

Rapid analysis of financial statements calculates key performance parameters, the so-called financial ratios, which help the auditor to identify critical areas of reporting and identify bottlenecks, and then develop an audit program, taking into account the risks of conducting a substantive audit. In international practice, there are more than 200 financial indicators that are used in the analysis of the activities of companies [6]. These indicators can be grouped as follows:

- liquidity indicators;

- financial stability indicators;

- indicators of turnover;

- profitability indicators.

These financial indicators can be calculated at the planning stage, as part of analytical procedures, using the indicators presented in the Balance Sheet of the Income Statement. In the course of analyzing the indicators based on the results obtained, the head of the audit team can optimize the audit. The indicators will show the areas of «risk», i.e. it is possible to optimize the verification of the reporting items at the stage of substantive verification. Optimization occurs due to the allocation of labor and time resources, when more detailed consideration is given to risk areas.

The current liquidity ratio is considered the most common indicator.

This indicator shows how much the company has enough funds to repay its short-term liabilities within a certain period. According to international practice, this coefficient should be approximately in the range from 1 to 2 (sometimes more than 3) [7, p. 308].

The term liquidity ratio is the ratio of the most liquid part of short-term assets to short-term liabilities. The regulatory level of the coefficient must also be higher than 1 .

This indicator shows whether the company can repay short-term liabilities using the most liquid assets.

When calculating the term liquidity indicator, a positive conclusion can be made about the company's liquidity in both cases, since the amount of the organization's short-term assets exceeds the value of its short-term liabilities. This indicator shows how much the company is dependent on external loans. If the coefficient has a high value, the lower the level of solvency and the high risk of a shortage of money [7, p. 297]. To characterize this indicator, it is necessary to know the levels of the coefficient for the industry, the specifics of the company's production activities.

The turnover ratios are useful for the analysis of financial statements, as well as conducting analytical procedures: first, they describe the business activity of the organization in the market; second, under certain conditions, they may indicate that a company is illiquid assets; third, they identify the specifics of the business depending on the industry.

So, this group includes three main coefficients:

$$
\begin{aligned}
& \text { Turnover ratio of accounts receivable }=\frac{\text { Average amount of accounts receivable }}{\text { sales volume }} \times 365 \\
& \text { Inventory turnover ratio }=\frac{\text { average carrying amount of inventory }}{\text { the volume of purchases }} \times 365 ;
\end{aligned}
$$




$$
\text { Fixed asset turnover ratio }=\frac{\text { sales volume }}{\text { average carrying amount of fixed assets }} \times 365 .
$$

This indicator is used when a production company is being checked, especially when analyzing fixed assets. And it shows the economic efficiency of production.

The low level of the coefficient may cause the auditor to have questions about the use of fixed assets in the production process. This level of return on capital may indicate a high level of investment in fixed assets, or insufficient efficiency in the use of assets, or a low level of sales.

For manufacturing companies, a high value of this indicator is preferable. And it means that for every tenge of revenue, the company invests less in fixed assets.

Profitability indicators demonstrate the overall performance of the company.

Gross profit margin is one of the profitability ratios used by auditors. This indicator is calculated using the following formula:

$$
\text { Gross profit margin }=\frac{(\text { revenue }- \text { cost price })}{\text { revenue }} \times 100 \% \text {. }
$$

Another factor is the return on sales, which shows how much tenge of net profit a unit of products sold brings.

The cost - effectiveness $=\frac{\text { net profit }}{\text { volume of products sold }}$.

Coefficients play a role in the audit process. For audit purposes, it is advisable to consider the margins in the dynamics for certain periods (often month, quarter, year).

According to the analysis of the coefficients it is possible to draw the following conclusions:

- if the liquidity indicators are normal values, this means that JSC (LLP) is quite stable in the market is functioning, and the auditor is not necessary to doubt the validity of the "principle of continuity»;

- if the financial stability indicators show a slight dependence of the JSC (LLP) on external sources of financing, this allows the auditor to do without conducting basic procedures for the audit of borrowed funds;

- if the turnover rate of accounts receivable is low, it means that you need to pay attention to the amount of accounts receivable. And this will require expanding the analytical procedures for determining doubtful debts, and including them in the company's assets;

- if the capital return ratio is low, this indicates the need to evaluate fixed assets, and analyze the use of fixed assets during analytical procedures.

If the indicators do not correspond to the normal values, the auditor should pay attention to the pricing, to the composition of the company's customers. And such procedures require both time and expertise of the auditor.

The analytical procedures considered at the stage of planning the audit were conditionally divided into three groups: testing the reports for possible errors, «reading» the reports, horizontal and vertical analysis, and express analysis of the reports. They help the auditor determine the direction and strategy of the audit, its plan, and the scope of the audit. In addition, they are aimed at identifying problems in the disclosure of information in the financial statements, and identifying risk areas at the substantive review stage. The use of analytical procedures at the audit planning stage will allow you to create an audit program with minimal time costs, as well as reduce the risks of problems that are associated with a lack of time and skills of personnel.

\section{LIST OF LITERATURE}

1 Kazakova N.A. Analytical procedures: experience of use in audit and evaluation of economic activity / N.A. Kazakova // Bulletin of the Financial University, 2017. - Vol. 21. No. 2 (98). - P. 113-120.

2 Tereshkina A.V. Analytical procedures for audit planning // Izvestiya Sankt-Peterburgskogo ekonomicheskogo universiteta, 2011. - No. 2. - P. 141-143.

3 Surnina E.S. Teoreticheskie osnovy analiticheskikh procedurov $\mathrm{v}$ audite // Mezhdunarodniy bookkeeping. -2010 . - No. 13. - P. 59-63. 
4 Alibekov Sh.A. The use of analytical procedures in audit activities // Audit statements. 2004. - No. 3. P. 59-62.

5 Grachev A.V. Economic interpretation of the balance sheet // Audit and financial analysis. 2013. No. 5. - P. 11-20.

6 «On approval of financial reporting forms of public companies» Order of the Minister of Finance of the Republic of Kazakhstan dated 02.06.2017.

7 Sheremet A.D. Analysis and diagnostics of financial and economic activities of the enterprise. - Infra M. - Moscow, 2009. -366 p.

\author{
А.С. БИКТЕУБАЕВА, ${ }^{1 *}$ \\ э.Ғ.К., доцент. \\ *e-mail: a.bikteubayeva@turan-edu.kz \\ Қ.Ж. ЕЛШІБЕКОВА, ${ }^{1}$ \\ M.э.H. \\ e-mail: k.elshibekova@turan-edu.kz \\ ${ }^{1}$ «Тұран» университеті, Қазақстан, Алматы қ.
}

\title{
АУДИТТІН ЖОСПАРЛАУ САТЫСЫНДА АНАЛИТИКАЛЫҚ ПРОЦЕДУРАЛАРДЫ ҚОЛДАНУ
}

\begin{abstract}
Аңдатпа
Авторлар осы мақалада аудиттің негізгі кезеңдерін қарастырады. Олар аудиторлық жоспарлаудың басты мақсатына қол жеткізуге мүмкіндік береді, яғни мүмкін болатын қателерді анықтау үшін есептілік тестін жүзеге асыру; ықтимал қателіктердің болуына есептілікті тестілеу; көлденең және тік талдау және есептілікті «оку»; есептілікті жедел талдау. Аудитті жоспарлау кезеңінде қаржылық есептілік нысандарындағы сәйкессіздіктер, динамика мен құрылымдағы елеулі өзгерістер анықталғаннан кейін коэффициенттерді анықтауға болады және бұл ретте есептілікті жедел талдау әдісі қолданылады. Мақалада қаржылық есептіліктегі негізгі қателіктерге назар аударылады. Сондай-ақ қаржылық есептілікті талдаудың негізгі коэффициенттері: өтімділік; қаржылық тұрақтылық; айналымдылық; рентабельділік коэффициенттері келтіріледі. Мақалада ұсынылған аудитті жоспарлау кезеңінде аудиторлар басшылыққа алатын аналитикалық процедураларды бірнеше топқа бөлуге болады. Бұдан басқа, аудиторлық рәсімдерді бөлу қаржылық есептілікте оны ашу кезінде ұсынылған ақпараттағы проблемаларды уақтылы анықтауға ықпал етеді және мәні бойынша тексеру кезеңінде аудиторлық тәуекелдерді анықтауға бағытталған. Аудитті жоспарлау кезеңінде аналитикалық процедураларды қолдану уақытты аз жұмсай отырып, аудиторлық бағдарламаны құруға, кадрлардың жеткіліксіз уақтылығы мен біліктілігіне байланысты проблемалардың пайда болу қаупін азайтуға мүмкіндік береді.
\end{abstract}

Тірек сөздер: аудит, есептілік, аудиторлық тексеру, талдау рәсімдері, жоспарлау, аудиторлар, қаржы.

\author{
А.С. БИКТЕУБАЕВА, ${ }^{1 *}$ \\ к.э.Н., доцент. \\ *e-mail: a.bikteubayeva@turan-edu.kz \\ К.Ж. ЕЛШИБЕКОВА, ${ }^{1}$ \\ М.Э.H. \\ e-mail: k.elshibekova@turan-edu.kz \\ ${ }^{1}$ Университет «Туран», Казахстан, г. Алматы
}

\section{ИСПОЛЬЗОВАНИЕ АНАЛИТИЧЕСКИХ ПРОЦЕДУР НА ЭТАПЕ ПЛАНИРОВАНИЯ АУДИТА}

\begin{abstract}
Аннотация
В данной статье рассматриваются основные этапы проведения аудита. Они позволяют достичь главной цели аудиторского планирования, то есть осуществление теста отчетности на определение возможных ошибок; тестирование отчетности на наличие вероятных погрешностей; горизонтальный и вертикальный анализ
\end{abstract}


и «чтение» отчетности; экспресс-анализ отчетности. На этапе планирования аудита уже после раскрытия несоответствий в формах финансовой отчетности, значительных изменений в динамике и структуре возможно определение коэффициентов, и при этом используется метод экспресс-анализа отчетности. В статье делается акцент на основные ошибки в финансовой отчетности. Также приводятся основные коэффициенты анализа финансовой отчетности: коэффициенты ликвидности; финансовой устойчивости; оборачиваемости; рентабельности. Аналитические процедуры, которыми руководствуются аудиторы на этапе планирования аудиторской проверки, представленные в статье, можно разделить на несколько групп. Кроме того, деление аудиторских процедур способствует своевременному выявлению проблем в информации, представленной при ее раскрытии в финансовой отчетности, и направлено на выявление аудиторских рисков в период проверки по существу. Использование аналитических процедур на этапе планирования аудиторской проверки даст возможность сформировать программу аудиторской проверки с минимальными затратами времени, уменьшить риски появления проблем, связанных с недостаточной своевременностью и квалификацией кадров.

Ключевые слова: аудит, отчетность, аудиторская проверка, аналитические процедуры, планирование, аудиторы, финансы. 